ELORE (ISSN 1456-3010), vol. 16 - 2/2009.

Julkaisija: Suomen Kansantietouden Tutkijain Seura ry.

[http://www.elore.fi/arkisto/2_09/katsart_palmenfelt_2_09.pdf]

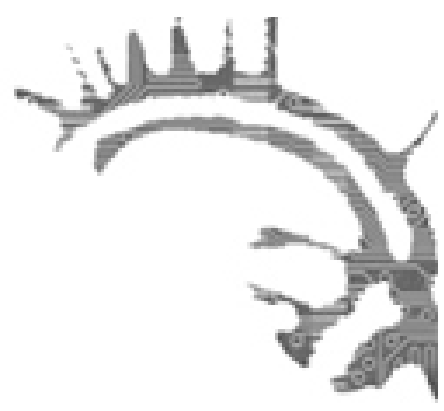

REVIEW ARTICLE

\title{
Contemporary Uses of Narrative
}

\section{$\underline{\text { Ulf Palmenfelt }}$}

Folklorists have been collecting and analyzing narratives for 200 years, all the way since the days of the Grimm brothers. We and our academic forefathers have spent many scholarly hours to develop methods for text and genre analysis and for understanding the communicative and performative uses of narratives. Of course, we have been aware of how narrative analysis is also a central concern for literary scholars, theater and film analysts, to mention representatives from just a few other academic disciplines. And we know that medical doctors, psychiatrists, psychologists, and other therapists as well as police interrogators and lawyers work professionally with narratives. All the same, within the field of oral narrative or folk narrative we have regarded ourselves as the indisputable experts. For some time now, however, our self appointed monopoly has started to be contested by groups of people outside the academic world, who use the concept of narrative in different ways.

Political chroniclers, for instance, have started to use the word narrative in new grammatical contexts, claiming that countries, politicians, or even material things are narratives. News journalists are leaving their role as reporters, starting instead to tell stories. Producing companies use narratives as a tool for brand building, and company leaders develope techniques to use narratives in their leadership.

Superficially, these four phenomena may seem to have nothing more in common than the fact that they all have some kind of relationship to the concept of narrative. As a folklorist, however, I can see a connection when I take my starting point in an analysis of the basic structures of the narrative form. A detailed understanding of the basic epic structures can reveal what qualities make narratives so attractive for story telling news journalists as well as for company directors who want to sell their brand or their vision of the business culture. Likewise, the new grammatical uses of the concept of narrative can be explained if we suppose that a (even unconscious) 


\section{Ulf Palmenfelt}

knowledge of these basic epic structures can be expected to evoke predictable connotations in the minds of the readers.

The discussion of this academic question may be intellectually challenging and possibly scholarly rewarding, but could also be regarded as a political issue concerning democratic ideals.

\section{Use and Abuse of Culture}

In some respects the situation may be compared to how ethnologists and anthropologists for almost a century (since Edward B Tylor's classic 1871 definition) were the only ones to use the concept of culture in a broad sense to describe the value systems and the organizations of groups and societies. During the 1970s that situation changed and the word culture was on everybody's lips. Commercial enterprises started to discuss their own management culture, political parties tried to improve their culture of decision making, and news journalists explained social tension and criminal behavior in terms of cultural differences or cultural clashes.

On the one hand we as academics had a reason to feel proud that our pedagogical ambitions had proven successful so that a broad public had been made aware of the importance of culture in society's everyday life. On the other hand, the non-academic use of the concept of culture sometimes has come close to being an abuse.

Among Swedish news journalists it has become a habit to use the concept of culture to designate non-Swedishness. Being Swedish, according to this world view, is the normal, that which does not have to be explained, questioned or defended. Everything else and everybody else is "cultural", thus marking their deviance which not seldom also is regarded as problematic. Instead of analyzing the origins of social problems, journalists sometimes overemphasize the dramatic potential of conflicts involving ethnic aspects and content themselves with labeling them as "cultural clashes".

Since Classic times, the concept of culture has been used as a contrast to nature to designate man's manipulation of nature (to cultivate land, agriculture), but also figuratively or metaphorically about human civilization (to cultivate the mind, high culture). Lately, Swedish news journalists have been relocating this old border-line between culture and nature and established a new boundary that runs between normality (equaling, of course, Swedishness) on the one hand, and, on the other, both culture and nature, which are thus placed together on the far side of the line. "The Others", all the beings on the wrong side of the border-line belong to cultures that emphasize man's biological, animalistic sides, close to uncivilized nature. "The Others" practice polygamy, they are sexually uncontrolled, but they circumcise their women, they threaten their daughters with honor killings and they educate their sons to become suicide bombers. Culture is thus made to equal nature and is supposed to be significant for the non-Swedish "Other".

Furthermore culture is treated as if it were genetically inherited, uniform, homogeneous, permanent, mandatory, and collective. According to this usage of the concept of culture, it is assumed that people are born into a certain culture, there 


\section{Contemporary Uses Of NarRative}

are no variations within each culture, cultures never change; as an individual you are not free to accept some parts of your culture and deny others, and everybody within a culture conforms to it totally and unconditionally. This practice treats culture like closed boxes, each containing identical, undeviating and everlasting samples of "culture bearers".

(Ab)uses such as these of the concept of culture by the mass media represent a democratic threat, since the result is a dangerous reduction of complicated and multifaceted social processes into simplified dichotomies of "us - the normal" and "them - the deviant".

\section{Basic Epic Patterns}

My argument in this review article is based on the premise that some of the phenomena I mention can be explained out of an understanding of the cultural form of narrative. Epic or narrating texts deal with outer change, with movement and development. The situation described in the beginning of the narrative is brought out of balance by some complicating factor that forces a change to take place and this leads to a new situation of balance. Longer narratives are built up by chains of such episodes, with a constant oscillation between equilibrium and disequilibrium that pushes the action forward towards the final resolution.

These chains of action are held together by chronology and logic: "first happened A and after that and because of that, B happened". The relationship between time and causality is so close that we are seldom confused when a narrator chooses to retell the episodes non-chronologically in the form of flash-backs, flash-forwards or parallel actions.

Narratives have beginnings and ends and clear story-lines, meaning that narrators not only have made a selection of what to include in their stories, but, equally important, what they have chosen to omit. The pendulum movement between balance and unbalance is maintained by the field of tension between oppositional forces. In its simplest - and rhetorically most powerful - form the pattern is built on two opposites only. Narratives are easily composed around dichotomies like good / bad, right / wrong, we / they.

The narrative pattern also encourages stereotypical role characters that are easy to relate to these dichotomies. The narrated world is peopled (1) by heroes, who support everything that is good because they have an urge to force development forward, and (2) by villains, who support everything that is evil because their aim is to stop development or to turn it backwards, and (3) by victims, who support the good side, but are too weak to conquer the bad forces and who will suffer if the heroes fail.

\section{Narrative as a Metaphor}

During the last two decades, on the Swedish mass media scene, a similar metamorphosis as the one described above about the concept of culture, seems to be taking 


\section{Ulf Palmenfelt}

place in relation to the concept of narrative.

In the 2006 Swedish parliament election campaign one Swedish newspaper described the two competing political leaders in terms of narratives (SvD Oct 2,2005). The headline was "The Best Story Will Win". Another newspaper wrote: "Two different stories about Sweden are competing in next year's election" (DN Oct 30, 2005). A third journalist wrote about a dominant "anti-narrative" about the Swedish welfare society as being nothing but an empty back-drop and evil mendacity (DN Nov 20, 2005).

To explain why he was more affected by the devastation caused by the hurricane Katrina in New Orleans than by flood catastrophes in Bangladesh, one journalist wrote that "the USA is its narrative" (DN September 11, 2005). Another journalist accused the Swedish television for transforming people's lives into narratives by televising the funeral ceremony for a murdered and sexually abused child (SvD May 24, 2008). Aftonbladet criticized a television documentary about former Prime Minister Göran Persson, because it was not a "reasonable" narrative (Aftonbladet March 27, 2007).

In the complimentary magazine on board the Arlanda express trains, I read that the editors want to collect the travelers' narratives and that the best ones will be read out in "story showers" in Arlanda airport's waiting hall (Xpress, November 2007, 7). In an airline onboard magazine I find an advertisement for a red wine brand that is "full of stories" and in a design magazine I read about carpets that "narrate the room."

As far as I understand it, the new linguistic construction is that the verb narrate is used together with other objects than story. Earlier you could narrate a narrative, you could tell a story. Nowadays, a political candidate can narrate him- or herself, carpets can narrate a room; a country, a historical period or a political agenda can be a narrative. Material objects, situations and phenomena can be defined as narratives.

Small and very informal investigations that I have made among friends and colleagues from other European countries, confirm similar mass media uses of the local equivalents of narrative in many places.

One way of explaining these new uses of the concept of narrative is to regard them as metaphorical. The writers invite us to make the intellectual experiment to regard something as if it were a narrative. If this is so, writers that use the concept in this way must presume that the reader is familiar with the typical epic form. And probably they are right. Most likely we learn the basic structures of narrative at the same time as we learn to master other linguistic features of our mother tongue. It can be expected that our brains, more or less unconsciously, try to interpret our impressions and experiences in terms of epic patterns.

In our daily lives, we seem to be attentive to possible logic connections and we are eager to understand the chronological order between episodes we experience or hear about. It seems natural to us to understand the reality we are experiencing as chronological chains of cause and effect.

When something is pointed out to us as being a narrative, we are probably supposed to start looking for possible causal relationships. Who or what caused that effect? And who is the narrator that has composed this narrative and for what purpose? A narrative is, as we all know, not a neutral account of objective facts, but something else. As readers or listeners, we are invited to start to think in terms of conspiracies and 


\section{Contemporary Uses Of NarRative}

propaganda. And the person pointing this out to us is the journalist or the chronicle writer. We are offered the opportunity to feel smart because we have seen through the attempt to fool us, and, the writer who made us pay attention to the trick stands out as even smarter.

By naming a person, an object, a situation, or a phenomenon a narrative, the writer invites the reader to start looking for hidden patterns, to become suspicious against the origin of the story, and to feel admiration and gratitude for the sharp-sighted analyst who made us all aware of the concealed agenda.

That which is pointed out as being a narrative is:

- an autonomous unit held together by a consistent inner logic of its own,

- promoting development ideologically or socially towards a definite direction with,

- artificially constructed by somebody who has a an outspoken agenda.

These qualities or the alleged contents of them are sometimes presented as if it they had been consciously kept hidden by evil forces and that the writer making them public has accomplished a daring revelation in the service of democracy. In my opinion, this use of the concept of narrative might on the other hand represent a threat to democracy. If journalists and political chroniclers encourage us to understand material objects, situations and phenomena as narratives, the resulting impression might be a world view built up around secret conspiracies, hidden agendas, and invisible, and thus uncontrollable, social and economical forces.

\section{The Stories of THE ENTERPRISES}

It is already long time since producing companies stopped selling products and instead started to sell brands. The idea was to charge a brand, symbolized by a logotype that was easy to recognize and to remember, with certain positive characteristics that would attract potential buyers. By smoking a certain cigarette brand you would feel free and independent like an American cowboy. By washing your hair with a certain brand of shampoo you would become healthy and feel close to nature.

Today the producing companies have realized that consumers are no longer attracted by such over-explicit messages and have abandoned them. At a conference about cultural heritage not long ago, however, I heard that today hundreds of thousands of local politicians all over the European Union are using huge amounts of tax payers' money to build and sell trustworthy brands for their local municipalities.

Meanwhile, the producing companies have started to sell stories about brands. Often such stories depict the founder of the company as a simple, honest and inventive person. Typical are the many stories circulating in Sweden about Ingvar Kamprad, the founder of IKEA, who is supposed to always travel by second class trains, who uses both sides of the paper in his note books, and who does not hesitate to help 


\section{Ulf Palmenfelt}

the staff on the floor at the opening of a new store. The founder of Fjällräven was an enthusiastic hiker from Northern Sweden who invented a light and practical rucksack because he had heard that Swedish children got problems with their backs from carrying their schoolbags in one hand only. A recent newspaper article reported that Fjällräven is now planning to introduce their products in North America and that their strategy is to "sneak into the market and slowly but steadily launch their products and the Fjällräven story" (Aftonbladet August 18, 2009. My italics).

\section{Corporate Storytelling}

Commercial enterprises have not only created stories about their brands. They have also developed techniques of using storytelling as a method of leadership that is regarded as being more efficient than the older techniques of coaching and team building.

The management consultant Stephen Denning has been one of the leading enthusiasts behind the method to use narration as a tool for leadership. The technique has been called organizational storytelling, corporate storytelling and storytelling management. Denning has developed his ideas in several books (e.g. Denning 2004, 2005), in lectures (which you also can buy on video cassettes or DVD), on his website and in e-mailed news letters. To introduce his methods, Stephen Denning has created a success story about himself. This is a quotation from his home page:

The origin of my interest in organizational storytelling was simple: nothing else worked. As a manager in the World Bank in 1996, I had been trying to communicate the idea of knowledge management and to get people to understand and to implement it. At that time in that organization, knowledge management was a strange and generally incomprehensible idea. I used the traditional methods of communicating with no success. I gave people reasons why the idea was important but they didn't listen. I showed them charts and they just looked dazed. In my desperation, I was willing to try anything and eventually I stumbled on the power of a story, such as the following:

In June of 1995, a bealth worker in a tiny town in Zambia logged on to the website for the Center for Disease Control in Atlanta Georgia and got the answer to a question on bow to treat malaria.

This was June 1995, not June 2001. This was not the capital of Zambia but a tiny place six hundred kilometers away. This was not rich country: this was Zambia, one of the poorest countries in the world. But the most important part of this picture for us in the World Bank is this: the World Bank isn't in the picture. The World Banke doesn't have its know-how accessible to all the millions of people who make decisions aboutpoverty. Butjust imagine if it had. Think what an organization it could become. 


\section{Contemporary Uses Of NarRative}

In 1996 in the World Bank, this story had helped galvanize staff and managers to imagine a different kind of future for the organization and to set about implementing it. Once knowledge management became an official corporate strategy later that year, I continued to use similar stories to reinforce and continue the change. The efforts were successful: by 2000, the World Bank was benchmarked as a world leader in knowledge management. (See www.stevedenning.com, 5.5.2008.)

Stephen Denning has identified eight "narrative patterns" that can be used by company leaders to cope with different kinds of situations:

- Motivate Others to Action: Using Narratives to Ignite Action and Implement New Ideas

- Build Trust in You: Using Narrative to Communicate Who You Are

- Build Trust in Your Company: Using Narrative to Build Your Brand

- Transmit Your Values: Using Narrative to Instill Organizational Values

- Get Others Working Together: Using Narrative to Get Things Done Collaboratively

- Share Knowledge: Using Narrative to Transmit Knowledge and Understanding

- Tame the Grapevine: Using Narrative to Neutralize Gossip and Rumor

- Create and Share Your Vision: Using Narrative to Lead People Into the Future (Denning 2005, vii-ix)

In his book, The Leader's Guide to Storytelling (2005), Denning discusses the qualities required by the stories that are created to solve management problems like these. In some shorter articles he displays his story templates in table form. If, for instance, your objective is to communicate who you are, you will need a story that provides audience-engaging drama and reveals some strength or vulnerability from your past. In telling it, you will need to include meaningful details, but also make sure the audience has the time and the inclination to hear your story. Your story will inspire such responses as "I didn't know that about him" and "Now I see what she's driving at". (Denning 2004, 5.)

\section{IF, ON THE OTHER HAND}

your objective is sparking action, you will need a story that describes how a successful change was implemented in the past, but allows listeners to imagine how it might work in their situation. In telling it, you will need to avoid excessive detail that will take the audience's mind off its own challenge. Your story will inspire such responses as "Just imagine..." and "What if...". (Denning 2004, 5.)

Of course Denning is right in his conclusion that different genres of narratives are more or less suitable for spreading different kinds of messages. Probably his method could be improved if he added some of the knowledge produced by folk- 


\section{Ulf Palmenfelt}

loristic genre theory and narrative analysis. The weak part of Denning's theory is its slightly mechanistic premise: if you hit that switch or turn that handle, this or that will happen. Folkloristic and linguistic studies of human verbal interaction have shown us the intricacies, the subtlety, and the artfulness performed in the transmission of knowledge or emotions.

\section{The Stories of the Politicians}

During Ronald Reagan's presidency (1981-1989), the White House spokesmen started to launch what they called "the line of the day", a simple and often emotionally moving news item that was distributed daily to the press or that came out as "sound bites" in all the speeches made by the President and other official representatives. Possibly Reagan with his background in Hollywood's film industry had developed a sense for the penetrative power of emotionally charged narratives in comparison to dry, factual reports.

Logically, the producers of "the line of the day" tried to formulate their texts in ways that would clarify the White House's stand on important and current issues. Sometimes it became obvious how their formulations would twist facts to make them appear more favorable from the American government's point of view. The text producers were said to "spin" their stories just like when a good pitcher spins a baseball to make it change direction during its flight through the air. Techniques were developed to choose the fitting facts or quotations, while disregarding the compromising ones, to overinterpret or deliberately misunderstand statements, and to use euphemisms and vague or ambiguous formulations. The experts were named "story spinners". Naturally, many of the journalists and political commentators who were supposed to distribute the messages on to the public were unwilling to take the role as passive transmitters. Clever interpreters, who were reputed to be able to reveal the real intentions behind the spinning stories, were called "spin doctors".

During the presidency of George W. Bush, these daily messages were expanded "into the story of the day", which in the White House's own vocabulary were to be sold to the media. When the fabricated stories deviated too much from what the journalists could observe, discussions started about whose reality was the true one. The journalist Ron Suskind wrote in an Esquire article about how he had been rebuked by a White House spokesman for having published an article that was critical towards the President. The spokesman said that journalists like Suskind lived in "what we call the reality-based community," which he defined as "people who believe that solutions emerge from your judicious study of discernible reality". Suskind nodded and murmured something about enlightenment principles and empiricism. The White House representative cut him off and went on:

That's not the way the world really works anymore. We're an empire now, and when we act, we create our own reality. And while you're studying that reality - judiciously, as you will - we'll act again, creating other new 


\section{Contemporary Uses Of NarRative}

realities, which you can study too, and that's how things will sort out. We're history's actors - - and you, all of you will be left to just study what we do. (Suskind 2004, 6.)

\section{News Stories}

In the beginning of the 1990s, I made a study of how news journalists built up their stories using several patterns well known from $19^{\text {th }}$ century legend or fairy tale tellers (Palmenfelt 1995). (Already at that time, US cable channels' newscasts used to start with the announcement: "Here are tonight's stories.")

The world view of the news stories could be seen as a system of concentric circles similar to that of the old folk legends. The center circle in both systems represented the security center of the "we"-group of the stories. In the legends, the we-group was normally the farmer's family and the security center was the kitchen of the farm house or the space in front of the open hearth. In the 1990s' news stories, we-groups were "we Swedes", "we taxpayers", "we families with school children", "we car owners", or "we consumers". The security zones were the own apartment, condominium, or house, the children's school or kindergarten, but hardly working places, shopping malls or public transportation. The modern equivalents to the supernatural beings that every day threaten to penetrate the security shields and spread awe and terror among "us" were drug addicts, escaped mental patients, paedophiles, immigrants, but also stock market speculators, bank managers, and foreign secretaries of the Treasury.

In September 1992, Sweden experienced a heavy financial crisis, due to a dangerously low liquidity ratio in many banks. The situation was financially risky for Sweden as a nation then outside the European Union, and it was even more critical for the Swedish banking system. In the aftermath of the acute crisis, banks were closed, reorganized or fusioned, many bank directors had to leave their positions, and much of the economic loss was covered by tax payers' money. News journalists understood the seriousness of the situation, but faced a problem of how to create dramatic stories out of invisible components like interest rates, rates of exchange, or liquidity ratios.

Their solution was to create a fairy tale scenario, where the sitting prime minister and the opposition leader were given the roles of the two older brothers in the fairy tale. They were described as self confident, but selfish and short-sighted. The invisible market was described as the ferocious monster, the dragon with seven fire-spitting heads, each day demanding his terrible tribute. Personified victims (shown in pictures) were employees at the financial market of a Gothenburg bank. In an article, these sober, well educated persons in white shirts, neck-ties and correct dresses, were said to be terrified, in shock, running to and fro and screaming. The journalists gave the role of the clever, unselfish brother to two younger politicians, a male and a female, one from each of the two major political blocks. According to the news stories, their intelligence and consideration made the two older brothers listen to reason. So, the thrilling fairy tale came to a happy ending. The political leaders could leave the arena with their pride intact, confirming that even if the situation sometimes looks critical 


\section{Ulf Palmenfelt}

we can always rely in our politicians, and in our political and economical system.

My 1995 article ended with these words:

So the news journalists persistently continue, day after day, year after year to build their own reality construction. As modern legend narrators they have taken over motives and forms of expression that generations of narrators have tried out as being the most efficient provokers of emotional reactions in an audience. Constantly the journalists find new atrocities with which they can horrify their readers and constantly the news agencies cable out fresh doses of oddities to amaze us and to make other news items stand out as more serious. In the folklorized reality of the mass media, memory seldom lasts longer than one week. There is no history, no continuity, everything happens now and will be forgotten tomorrow. (Palmenfelt 1995, 67.)

The metamorphosis transforming journalists from neutral reporters of objective facts into constructors of simplified tales of right and wrong has since then continued at an escalated scale. Today, even newspapers, radio and television channels that wish to be regarded as serious present their news in the form of narratives. Academic journalist education programs include courses in "narrating journalism" and "the narrative technique of reporting".

\section{ConClusion}

I believe that most of these contemporary uses of narrative that I have mentioned here, can be understood and explained by looking at narrative as a cultural form that selects and orders events into units of logical and chronological chains. The basic features of the narrative form makes it suitable not only for telling fairy tales, jokes, or personal experience stories, but also for selling commercial brands, spinning political interpretations, managing commercial companies, and telling news stories.

Some of the basic epic characteristics mentioned in this review article explain why narratives function as building stones in our joint understanding of culture, of society and of what it means to be human. We all use narratives to create order, meaning and cohesion out of our sometimes chaotic experiences of a changing and elusive world. The narrative structures we have internalized in our minds, urge us to look for causality in our lives. We use narratives to label our fellow-creatures in accordance with stereotypical roles. We build our self-images as individuals, groups, and nations with the help of different levels of grand narratives.

But these positive and helpful qualities can be abused. Building stones can also be used to build enclosures and prison walls.

If I am right in comparing how journalists took control over the concept of culture 


\section{Contemporary Uses Of NarRative}

with their attempts to take over the concept of narrative we have to be careful, for narratives are bad at:

- describing status quo, solidarity and harmony,

- representing disorder, chaos, irrationality,

- representing complicated personalities and sliding gray scales,

- describing complicated relationships and contradictory courses of events.

When commercial enterprises use narratives to sell their brands, customers are invited to enter fictitious tale worlds, where material goods, consumption and commercial success represent the good forces that promise to lead us towards the happy ending.

With their construction of fitting stories, company leaders threaten to pigeonhole their employees into stereotypical role patterns in theatrical plays written and directed by themselves, for the companies' - and possibly their own - benefit.

Politicians might always have used narratives to clarify their positions, exemplify their suggestions and make their visions logical, cohesive, and emotionally strong. Political discussion, however, deserves to be held in an argumentative, not a narrative mode to be serious. To examine different ideologies, to consider their social relevance, and to compare their consequences is an intellectual process totally different from telling simplified stories about right and wrong.

With journalists using narratives to describe reality, we can expect news stories characterized by reductionism, dramatization, and emotionalization that reduce complicated processes to simple black and white dichotomies of right and wrong, we and they, heroes and villains.

And, if journalists and political chroniclers claim that we should understand material objects, situations and phenomena as narratives, they create a reality where nothing is authentic, where nobody is honest, and where everyman's normal attitudes should be suspicion, irony and selfishness.

As students of cultural phenomena, we are well aware of the strength of protrusive social waves. They are seldom possible to stop or redirect, but have to die out by themselves when the wind slackens or their power is emptied against the rigid shore-line. Waiting for that, we should make use of the existing deep folkloristic knowledge about the structures and functions of narrative to document, analyze and maybe even question these contemporary uses of narrative.

\section{REFERENCES}

I read an earlier version of this paper at the 31st Nordic Ethnology and Folklore Conference, Helsinki on August 20, 2009. 


\section{LITERATURE}

Aftonbladet, August 18, 2009.

DENNING, STEPHEN 2004: Telling Tales. - Harvard Business Review.

- 2005: The Leader's Guide to Storytelling. Mastering the Art and Discipline of Business Narrative. San Francisco: Jossey-Bass.

- 2008: Steve Denning [online]. <www.stevedenning.com> [5.5.2008.]

DN = Dagens Nyheter, September 11, 2005.

- October 30, 2005.

- November 20, 2005.

PALMENFELT, ULF 1995: Den folkloriserade verkligheten. Två svenska kvällstidningar som historieberättare. - Selberg, Torunn (ed.): Nostalgi og sensasjoner. Folkloristisk perspektiv på mediekulturen. Turku: NIF.

RICH, FRANK 2006: The Greatest Story Ever Sold. The Decline and Fall of Truth in Bush's America. New York: Penguin.

SALMON, CHRISTIAN 2007: Storytelling, la machine à fabriquer des histories et à formater les esprits. Paris: La Découverte.

SUSKIND, RON 2004: Without a Doubt. New York Times Oct 17, 2004.

SvD = Svenska Dagbladet, October 2, 2005.

- May 24, 2008.

TYLOR, EDWARD B. 1871: Primitive Culture; Researches into the Development of Mythology, Philosophy, Religion, Art and Custom. London: John Murray (Publishers) Ltd. XPRESS, November 2007.

Ulf Palmenfelt is professor of ethnology at Gotland University, Visby, Sweden 